\title{
Relationships Among Seed Germination, Lithological Substrate and Growth in Two Quercus Species
}

\author{
Adrian FÜSTÖS ${ }^{1}$, Liviu HOLONEC ${ }^{1}$, Ioan TĂUT ${ }^{1}$, Tabita-Teodora LISANDRU ${ }^{1}$, Doru PAMFIL ${ }^{1}$, Florin- \\ Alexandru REBREAN ${ }^{1 *}$ \\ ${ }^{1}$ University of Agricultural Sciences and Veterinary Medicine Cluj-Napoca, Romania. \\ * corresponding author: florinrebrean88@gmail.com
}

Bulletin UASVM Horticulture 75(2) / 2018

Print ISSN 1843-5262, Electronic ISSN 1843-536X

DOI:10.15835/buasvmcn-hort: 2017.0042

\begin{abstract}
In Romania, Quercus is represented by five to nine species, depending on their taxonomic classification. The purpose of this study was to determine the seed germination rate and seedling growth of Quercus robur and Quercus petraea species in different soil conditions. The results obtained show that there are differences between trees growing and development. Our results show that seed quality and lithological substrate have an influence on seed germination of Quercus robur and Quercus petraea species. This fact has an important role in forest resource management.
\end{abstract}

Keywords: Quercus robur, Quercus petraea, seed germination, growth

\section{Introduction}

The Quercus genus is taxonomically assigned to the Fagaceae family, one of the richest families in terms of dendrology, with about 1.000 species all across the globe, separated into seven genres, spread across the northern hemisphere, from boreal to tropical or even equatorial (Kremer et al., 2007). Şofletea and Curtu (2007) describe the existence of nine species of Quercus in our country.

\section{Aims and Objectives}

The aim of this study was to determine the seed germination rate and tree growth of Quercus robur and Quercus petraea species in particular soil conditions. Germination is the most sensitive stage of the plant life cycle so we tried to evaluate plants behavior in soils with different $\mathrm{pH}$.

\section{Materials and Methods}

There have been collected 200 acorns of Quercus robur L. and Quercus petraea (Matt.) Liebl. in Hoia forest, Cluj-Napoca (Fig. 1), 100 of each species. Acorns have been sown in pots with two soil types with different $\mathrm{pH}$ (Fig. 2), as follows: 50 acorns of Quercus robur and 50 acorns of Quercus petraea were sowed in soil with $\mathrm{pH} 4$ and the other part of the acorns were sowed in soil with $\mathrm{pH}$ 6. After sprouting, the first observations on seedling growth ware made in three weeks, then other six measurements have been performed from three to three weeks until the plants reached approximately five months (21 weeks).

\section{Results and discussions}

The results obtained show that there are major differences of seedling growth on the two soil types (Fig. 3) studied. The most spectacular difference has been observed between Quercus petraea already after three weeks of growth on soil with $\mathrm{pH}=4(40 \mathrm{~cm})$ and the other three studied variants (about $20 \mathrm{~cm}$ ). Quercus robur grown on soil with $\mathrm{pH}=4$ presented a rather constant rate of growing in three, six and nine weeks after sprouting. For other six weeks there had been observed a stagnation and then a significant growth until the end of our experiment both on $\mathrm{pH}=4$ and $\mathrm{pH}=6$. A similar development in seedling growth can be observed in Quercus petraea, on soil with $\mathrm{pH}=6$ but with a slow rate of growing after 15 and 21 weeks. The highest growth level was reached by Quercus 


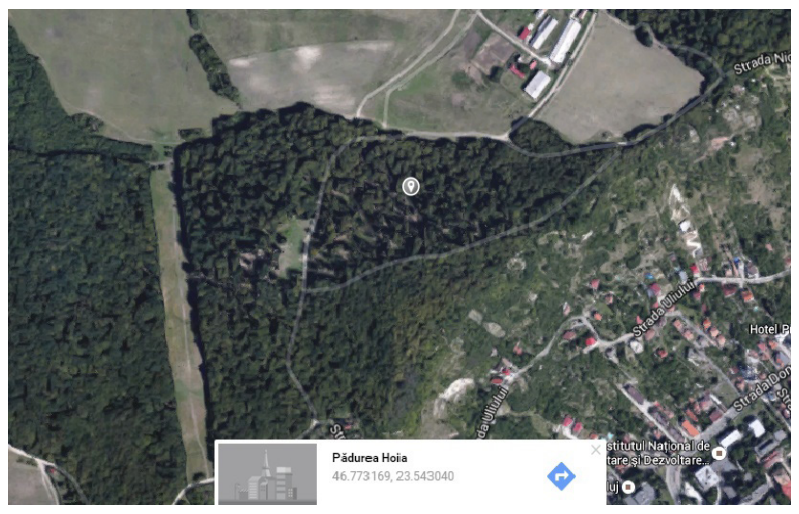

Figure 1. Hoia forest, Quercus robur and Quercus petraea seed harvesting site

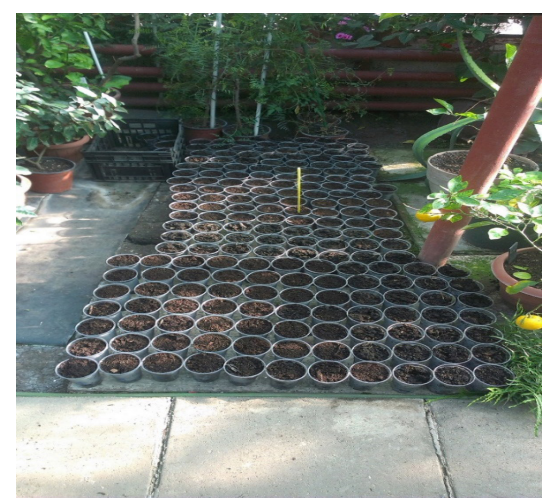

Figure 2. Acorns sown in pots containing soil with $\mathrm{pH}=4$ and $\mathrm{pH}=6$

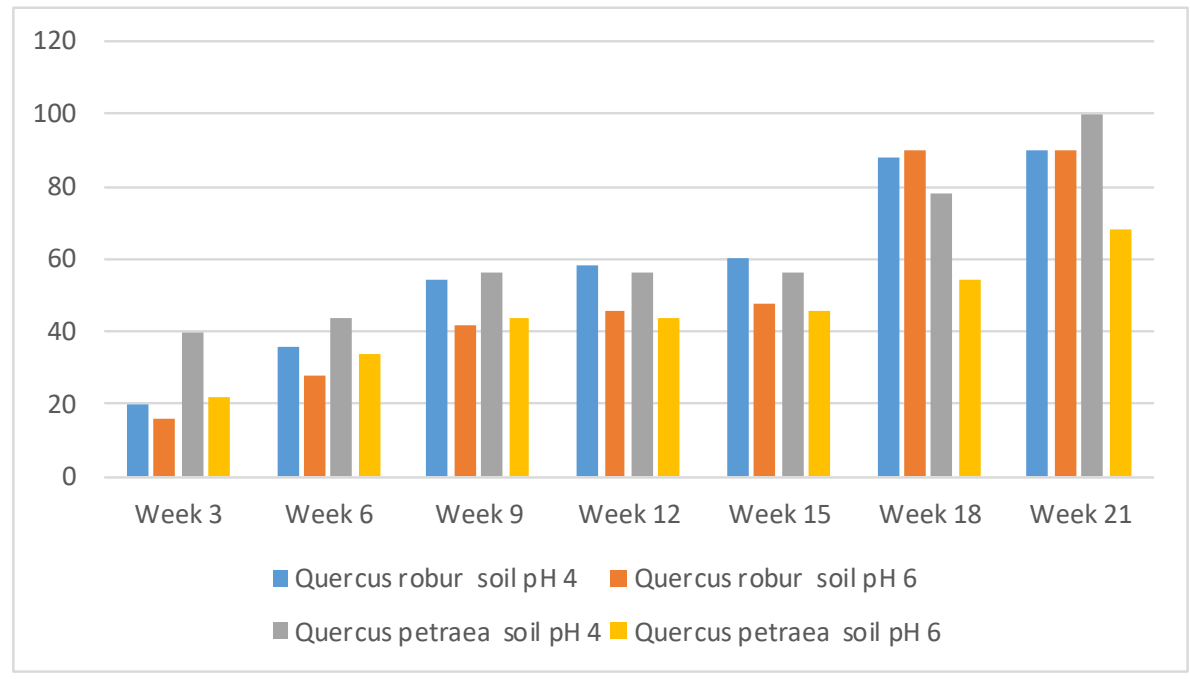

Figure 3. Oak plant growth in different soil conditions

petraea after 21 weeks $(100 \mathrm{~cm})$ while the lowest rate of growth $(68 \mathrm{~cm})$ of all studied variants has been observed in the same Quercus petraea on a soil with $\mathrm{pH}=6$.

\section{Conclusion}

Understanding the germination capacity of seeds is important for forest restoration and forest nurseries in order to set up new forest plantations. Our results show that seed quality and lithological substrate have an influence on seed germination of Quercus robur and Quercus petraea species.

As general aspect there can be concluded that both studied species presented a more constant and better growth on soil with $\mathrm{pH}=4$. Consequently, for a greater success of sprouting and seedling growth it is recommended to use acidic germinating substrates.
This fact has an essential role in forest resource management.

\section{References}

1. Kremer A, Casasoli, M, Barreneche T, Bodénès C, Sisco P, Kubisiak T, Scalfi M, Leonardi S, Bakker E, Buiteveld J, Romero-Severson J, Arumuganathan K, Derory J, ScottiSaintagne C, Roussel G, Bertocchi ME, Lexer C, Porth I, Hebard F, Clark C, Carlson J, Plomion C, Koelewijn HP, Villani F (2007). Genome Mapping and Molecular Breeding in Plants, Vol 7, Forest Trees. Springer, Berlin: 161-187.

2. Pritchard HW, Manger KR (1990), Quantal Response of Fruit and Seed Germination Rate in Quercus robur L. and Castanea sativa Mill, to Constant Temperatures and Photon Dose, Journal of Experimental Botany, 41(12):1549-1557.

3. Şofletea N, Curtu L (2007). Dendrology. Transylvania University Press, Braşov, 472p. 